\title{
Bioaccumulation of mercury in predatory fish from Amapá State, Brazil
}

\section{Bioacumulação de mercúrio em peixes predadores do estado do Amapá, Brazil}

\author{
Cecile de Souza Gama1, Luís Mauricio Abdon da Silva² \\ ${ }^{1}$ Instituto de Pesquisas Científicas e Tecnológicas do Amapá, Núcleo de Biodiversidade, Rod, JK, Kn 10 s/n. Fazendinha, Macapá - AP, Brasil. \\ https://orcid.org/0000-0002-5128-6120 E-mail: cecilegama@hotmail.com. *Corresponding author \\ ${ }^{2}$ Instituto de Pesquisas Científicas e Tecnológicas do Amapá, Núcleo de Biodiversidade, Rod, JK, Kn 10 s/n. Fazendinha, Macapá - AP, Brasil. \\ https://orcid.org/0000-0001-9510-0933 E-mail: luis.abdon13@gmail.com
}

\section{Key-words \\ Mercury contamination Hg bioacumulation Amapá}

Bioaccumulation of $\mathrm{Hg}$ in aquatic systems varies considerably according to the food chain structure and age of fish. As fishes are an important food resource in the Amazon region, common species of carnivorous and piscivorous fish in Amapá State were analyzed for contamination by Mercury. Specifically, the influence of standard length and weight of individuals on the observed $\mathrm{Hg}$ concentrations was investigated and used to evaluate whether bioaccumulation rates vary among different species. The fishes were collected from five locations in Amapá State between August 2017 and May 2018. We measured the total mercury content in 204 specimens representing nine carnivorous/piscivorous species of fishes: Serrasalmus rhombeus, Plagioscion squamosissimus, Megalops atlanticus, Hoplias malabaricus, Cichla monoculus, Brachyplatystoma vaillantii, Boulengerella cuvieri, Ageneiosus inermis and Hoplias aimara. All fishes had some level of Hg contamination and the potential for bioaccumulation of this contaminant varied among species. A positive relationship between weight and/or length and the total body $\mathrm{Hg}$ concentration was observed only for Serrasalmus rhombeus, Hoplias malabaricus, Cichla monoculus and Brachyplatystoma vaillantii.

\section{Palavras chave \\ Contaminação de Mercúrio Bioacumulação de $\mathrm{Hg}$ Amapá}

\begin{abstract}
A bioacumulação de mercúrio em sistemas aquáticos varia consideravelmente de acordo com a estrutura da cadeia alimentar e com a idade do peixe. Como os peixes são um recurso alimentar importante na região Amazônica, espécies comuns de peixes carnívoros e piscívoros no estado do Amapá foram analisadas quanto à sua contaminação por mercúrio. Especificamente, foi observada a influência do comprimento padrão e do peso dos indivíduos na concentração de mercúrio encontrada e usada para avaliar se as taxas de bioacumulação variam entre as diferentes espécies. Os peixes foram coletados em cinco localidades no estado do Amapá entre agosto de 2017 e maio de 2018. Foram medidos o mercúrio total em 204 espécimes representando nove diferentes espécies de peixes carnívoros/piscívoros: Serrasalmus rhombeus, Plagioscion squamosissimus, Megalops atlanticus, Hoplias malabaricus, Cichla monoculus, Brachyplatystoma vaillantii, Boulengerella cuvieri, Ageneiosus inermis e Hoplias aimara. Todos os peixes apresentaram algum nível de contaminação por mercúrio e o potencial para bioacumulação deste contaminate variou entre as espécies. Uma relação positiva entre peso e/ou comprimento e a concentração total de mercúrio corporal foi observada apenas para Serrasalmus rhombeus, Hoplias malabaricus, Cichla monoculus and Brachyplatystoma vaillantii.
\end{abstract}

\section{INTRODUCTION}

Studies in the Amazon Basin show numerous examples of aquatic systems contaminated by mercury $(\mathrm{Hg})$. For the fishes that inhabit these systems, the concentration of mercury is closely linked to their feeding regime and position in the trophic web (FRÉRY et al., 2001). Species at higher trophic levels have a higher mercury concentration when compared to species at the base of the food chain, such as herbivores (ZHOU; WONG, 2007; AZEVEDO-SILVA et al., 2016). This is because mercury, in the form of methylmercury, is easily absorbed by fish and other aquatic animals, which leads to its deposition in the tissues. The mercury accumulates in the biological chain over time (i.e., bioaccumulation), reaching concentrations much higher than those found in waters and sediments (AZEVEDO, 2003).

In general, the bioaccumulation of $\mathrm{Hg}$ in aquatic systems varies considerably according to the food chain structure and age of fish. In a simplified way, plankton is found at the base, followed by herbivores, then small to large piscivorous fish where the highest $\mathrm{Hg}$ concentrations are expected (BARBOSA, 2003). In fact, mercury concentrations in muscle tissue are approximately 10 times higher in carnivorous fish compared to herbivorous fish (BRUGGEMAN, 1982; CASTILHOS; BIDONE, 2000). For this reason, the top fishes in the food chain are widely used as bioindicators of mercurial contamination in aquatic ecosystems (RODDRIGUES et al., 2010). Fish age, measured indirectly by standard length, may 
(CARRASCO et al., 2011) or may not influence the accumulated levels of Hg (ROULET; MAURY-BRACHET, 2001; SAMPAIO DA SILVA et al., 2006; BASTOS et al., 2008) as a consequence of the exposure time.

Fishes are an important food resource in the Amazon region and a few studies have examined the bioaccumulation of mercury in specific parts of the basin (DOREA; BARBOSA, 2007; SOUZA-ARAUJO et al., 2016; LINO et al., 2018). Those studies determined that fishes are the main route of mercury contamination in the population, especially in villages along rivers where contaminated fishes are the main source of protein (MALM et al., 1995; BASTOS et al., 2007).

Common species of carnivorous and piscivorous fish in Amapá State were analyzed for contamination by Mercury. Specifically, the influence of standard length and weight of individuals on the observed $\mathrm{Hg}$ concentrations was investigated and used to evaluate whether bioaccumulation rates vary among different species.

\section{METHODOLOGY}

The fishes were collected from five locations in Amapá State between August 2017 and May 2018: Rio Cassiporé, near the Vila Velha community; Amapá Grande River, coastal region near its mouth and that of the Flexal River; Oiapoque
River, close to its mouth and in part of the Uaçá River; Araguari River, main channel and some major tributaries within the Flona do Amapá and PARNA Mountains of Tumucumaque; Amapari River, region close to its confluence with the Anacuí River in the PARNA Mountains of Tumucumaque (Figure 01)

Fish were caught by local fishermen hired to support the research project. According to the local fishermen, each fish species was captured using a particular gear such as gillnets, hand lines with hooks, fishing rods and long lines. Each specimen was identified to species level, weighed and measured. A minimum of $70 \mathrm{~g}$ of muscle tissue free of skin was removed from the dorsal region of the body. All dissection equipment was sterilized between samples to avoid contamination. Samples were stored on ice for transportation to laboratory freezers.

Total mercury analysis was carried out in the Analytical Chemistry Laboratory of the the Pontific University of Rio de Janeiro, using Cold Vapor Atomic Fluorescence Spectrometry (EPA, 2002). The Analytical quality was determined by control strick blank with duplicate analysis and compared to analytical results of certified reference materials (DORM-2, Dogfish Muscle Certified Reference Material for trace element, National Research Council, Canada). Total mercury analysis from wet weight was adopted.

Figure 1. Study area showing sampling sites (GERCO 2020)

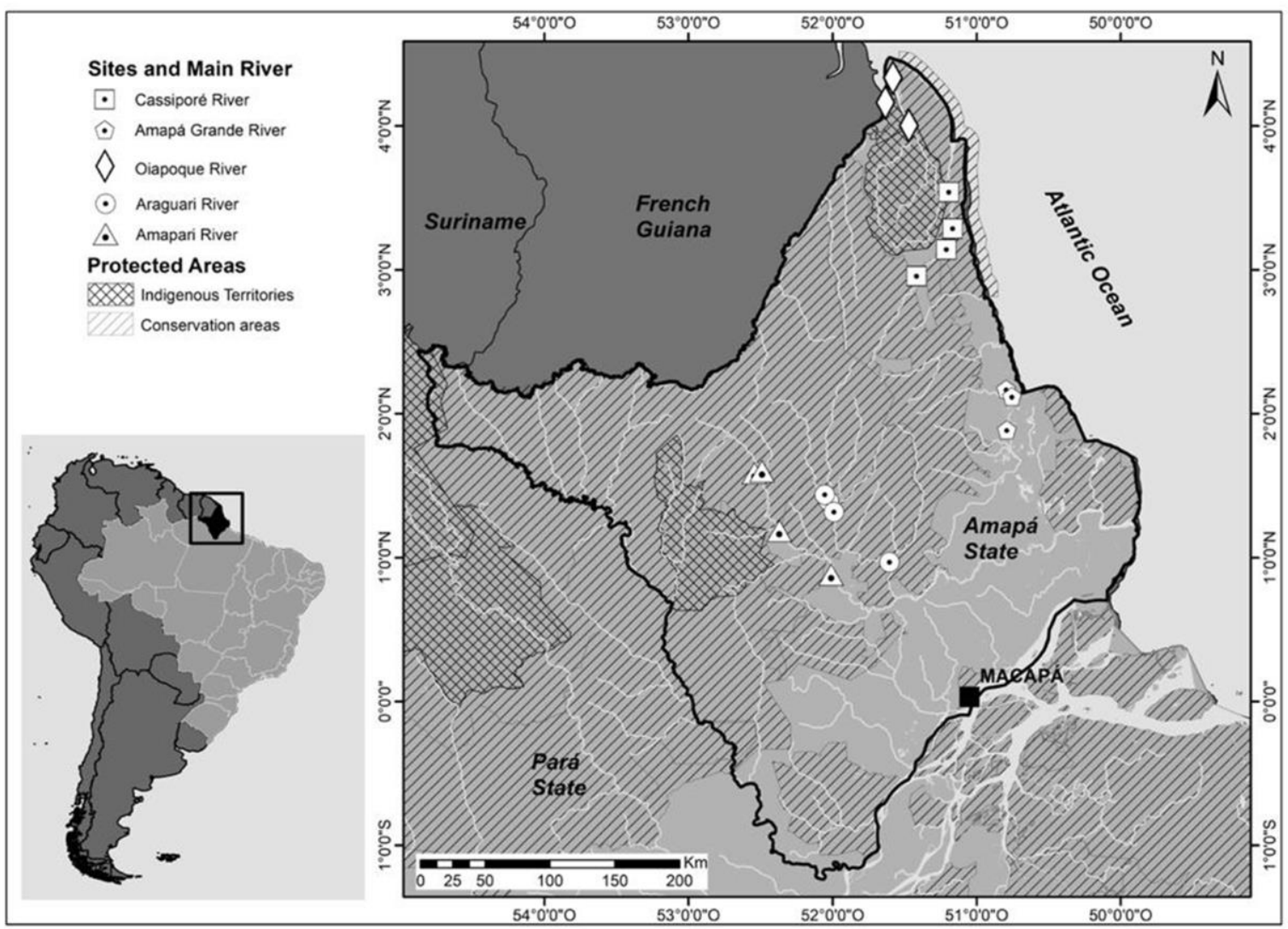


The tolerance limit recommended for consumption by the WHO is $0.50 \mathrm{mg} . \mathrm{kg}^{-1}$ for carnivorous and $0.30 \mathrm{mg} . \mathrm{kg}^{-1}$ for non-carnivorous fishes (IPCS, 1990). In Brazil, the $\mathrm{Hg}$ limits was set at $0.50 \mathrm{mg} . \mathrm{kg}^{-1}$ for nor-carnivorous and $1.00 \mathrm{mg} . \mathrm{kg}^{-1}$ for carnivorous fishes (MS, 1998; ANVISA, 2013).

Using a more conservative approach, we used the values established by WHO as a reference, since the daily consumption of fishes in the Amazon Basin is much higher than in other regions of Brazil.

The total weight / standard length relationship was determined after graphical inspection of the log data and then adjusted by the least squares method according to the expression:

$$
W t=a S l^{b}
$$

Where, Wt is the Total Weight (g), $\mathbf{S I}$ is the Standard Length $(\mathrm{cm}), \mathbf{a}$ is the linear coefficient and $\mathbf{b}$ is the slope of the regression.

The exponent $b$ must have values between 2.5 and 3.5 (usually 3 ). When $b=3$, the growth in weight is isometric; when different from 3 , the growth is said to be allometric, which can be positive $(b>3)$ or negative $(b<3)$ (KING, 1996). Relations were tested between the standard value of 3 using Student's t test (ZAR, 1996).

The length and weight data were used to determine the well-being or nutritional status of the fish, by calculating the relative condition factor $(\mathrm{Kr})$ according to the equation (LE CREN, 1951):

Wr=Mt/Me
Where:
$\mathrm{Mt}=$ Empirically recorded mass in grams;
$\mathrm{Me}=$ Theoretically expected mass in grams.

To calculate the theoretically expected values of mass (Me), the following equation was used:

$$
M e=\left(S I^{b}\right) \cdot a
$$

Where, Me is the expected mass, $\mathbf{S I}$ is the standard length; $\mathbf{a}$ the intercept or condition factor and $\mathbf{b}$, the angular coefficient of the potential curve or the allometry coefficient (LE CREN, 1951). Kr was calculated and tested with the $\mathrm{Kr}=$ 1.00 standard (LE CREN, 1951), using Student's t test, ( $p$ $<0.05)$ (ZAR, 1996).

To check for a relationship between standard length $(\mathrm{cm})$, weight $(\mathrm{g})$ and mercury concentration $(\mathrm{Hg})$, a regression analysis was applied. The dependent variable was the concentration of mercury while the independent variables were lengths and weights. According to Jacques-Callegari (2007) when the $\mathbf{r}$ (Pearson correlation coefficient) value is between 0 and 0.29 , the correlation between variables is weak, between 0.30 and 0.59 it is regular, between 0.6 and 0.89 it is strong and between 0.9 and 1 it is very strong.

\section{RESULTS}

Analyses were completed for total of 204 specimens representing nine carnivorous/piscivorous species of fishes: Serrasalmus rhombeus, Plagioscion squamosissimus, Megalops atlanticus, Hoplias malabaricus, Cichla monoculus, Brachyplatystoma vaillantii, Boulengerella cuvieri, Ageneiosus inermis and Hoplias aimara. The maximum, minimum and average values for the standard length and weight, as well as the total number of specimens analyzed by species, are shown in Table 01. Figure 02 shows the values for total $\mathrm{Hg}$ contamination ( $\mathrm{mg} . \mathrm{kg}^{-1}$ ) for each species. All of the fish analyzed showed some contamination by $\mathrm{Hg}$ and $39.7 \%$ of the specimens had levels above $0.5 \mathrm{mgk} \mathrm{kg}^{-1}$ (Table 01), the limit established by WHO for the consumption of carnivorous fish.

The regression analysis to check for a relationship between standard length $(\mathrm{cm})$, weight $(\mathrm{g})$ and mercury concentration $(\mathrm{Hg})$, are shown in Tables 03 and 04, respectively, and in Figures 03 and 04 when the results were significant.

\section{DISCUSSION}

All fishes had some level of $\mathrm{Hg}$ contamination, showing that this heavy metal is present in the environment. However, the potential for bioaccumulation of this contaminant varied among species. All species had piscivorous or carnivorous eating habits, and such species tend to have higher concentrations of $\mathrm{Hg}$ than omnivorous, detritivorous and / or herbivorous fishes (BASTOS, 2006; DOREA et al., 2006).

According to Cabana and Rasmussen (1994), trophic level and mean weight explain a large proportion of variation in $\mathrm{Hg}$ levels in fishes. Besides that, since the length of the fishes can be associated with age, a positive relationship between length and mercury concentration means an increase of concentration with time and that the fishes accumulated mercury throughout their lives. Thus, species that showed a positive relationship between body weight and length and the concentration of mercury in the muscle tissue constitute species with greater potential for bioaccumulation of this heavy metal. Based on this study, those species are: Serrasalmus rhombeus, Hoplias aimara, Brachyplatystoma vaillantii, Cichla monoculus and Hoplias malabaricus.

Plagioscion squamosissimus had low mercury 
Table 1. Maximum, minimum and average values for the standard length (Lp) and weight (Wt) of specimens analyzed by species

\begin{tabular}{|c|c|c|c|c|c|c|c|c|}
\hline \multirow{2}{*}{ Species } & \multirow[t]{2}{*}{$\mathrm{n}$} & \multirow{2}{*}{$\begin{array}{l}\% \text { above } \\
0.5 \mathrm{mg} / \mathrm{Kg}\end{array}$} & \multicolumn{3}{|c|}{$\operatorname{Lp}(\mathrm{cm})$} & \multicolumn{3}{|c|}{$\mathrm{Wt}(\mathrm{g})$} \\
\hline & & & Min. & Max. & Av. & Min. & Max. & Av. \\
\hline Serrasalmus rhombeus & 35 & 51.4 & 18.7 & 35.0 & 25.1 & 170.0 & 1500.0 & 596.0 \\
\hline $\begin{array}{l}\text { Plagioscion } \\
\text { squamosissimus }\end{array}$ & 14 & 0 & 28.9 & 39.8 & 33.6 & 435.0 & 1140.0 & 713.2 \\
\hline Megalops atlanticus & 23 & 0 & 33.0 & 55.7 & 41.6 & 550.0 & 3010.0 & 1288.2 \\
\hline Hoplias malabaricus & 16 & 18.8 & 22.8 & 34.5 & 26.8 & 235.0 & 940.0 & 412.2 \\
\hline Cichla monoculus & 12 & 33 & 21.0 & 53.5 & 31.3 & 245.0 & 5090.0 & 1177.9 \\
\hline $\begin{array}{l}\text { Brachyplatystoma } \\
\text { vaillantii }\end{array}$ & 17 & 0 & 33.6 & 50.7 & 40.8 & 500.0 & 2420.0 & 1144.1 \\
\hline Boulengerella cuvieri & 14 & 71.4 & 32.1 & 56.0 & 45.8 & 220.0 & 1800.0 & 1007.1 \\
\hline Ageneiosus inermis & 10 & 60 & 24.3 & 38.7 & 31.8 & 195.0 & 960.0 & 472.5 \\
\hline Hoplias aimara & 63 & 63.5 & 23.8 & 65.5 & 40.8 & 310.0 & 6110.0 & 1900.6 \\
\hline
\end{tabular}

Figure 2. Boxplot graph showing the $\mathrm{Hg}$ concentration values for each fish species analyzed.

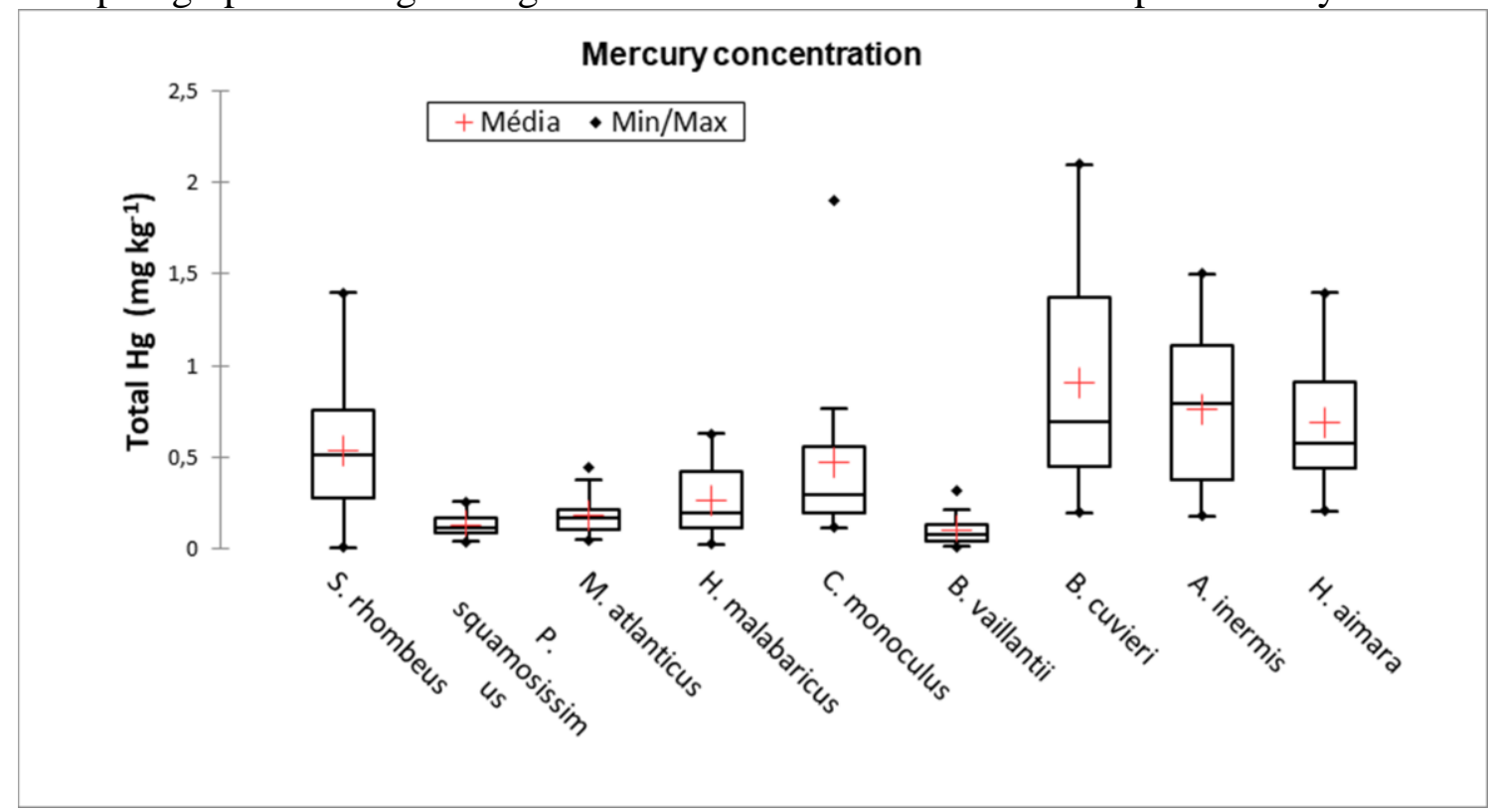

contamination, and no individual had a level above 0.5 mg.kg-1, the limit recommended by WHO for consumption of carnivorous fish. These results differ from those of Beltran-Pedreros (2011) in Lago Grande de Manacapuru (Solimões River) where this species showed levels above 0.5 mg.kg-1 of $\mathrm{Hg}$. Plagioscion squamosissimus showed isometric growth and no relationship was found between the levels of contamination by $\mathrm{Hg}$ and its weight or length. Similarly, Sampaio da Silva et al. (2006) found no such relationship in the Tapajós River, despite the carnivorous / piscivorous diet reported for P. squamosissimus (BELTRANPEDREROS, 2011; MÉRONA; RANKIN-DE-MÉRONA, 2004; DARY et al., 2017). When young, this species has a more general diet, feeding on crustaceans and insects (STEFANI; ROCHA, 2009). This may allow smaller individuals to avoid high $\mathrm{Hg}$ values, resulting in a non-significant relationship between these values and weight and length.

Serrasalmus rhombeus and Hoplias malabaricus showed high levels of $\mathrm{Hg}$ contamination and a positive correlation between $\mathrm{Hg}$ and body length and weight, results similarly found by Soares et al. (2016) in the Negro River basin. In the Tapajós river, Sampaio da Silva et al. (2006) found a positive relationship between $\mathrm{Hg}$ and the length of Serrasalmus rhombeus and Cichla monoculus, among other carnivorous / piscivorous species studied in the region. In the present study, $\mathrm{C}$. monoculus showed high concentrations of $\mathrm{Hg}$, and a positive relationship between this metal and its weight and length. Similar observations were reported for this species by Vera et al. (2008) in the Tapajós river and by Bastos et al. (2008) in the Madeira River. Soares et al. (2016) also found a 
Table 2. Length/Weight relationship analysis and Condition factor values (Kr) os al fishes analysed and conclusion of their growth type

\begin{tabular}{|l|c|l|r|l|l|l|}
\hline Species & $\mathrm{n}$ & $\begin{array}{l}\text { Lenght/Weight } \\
\text { relationship }\end{array}$ & $\mathrm{b}$-value & $\begin{array}{l}\text { Condition } \\
\text { fator Kr }\end{array}$ & Growth & Growth t-test \\
\hline $\begin{array}{l}\text { Serrasalmus } \\
\text { rhombeus }\end{array}$ & 35 & $\mathrm{~F}<0.0001$ & 3.49 & $\begin{array}{l}1.001 \\
(=1)\end{array}$ & $\begin{array}{l}\text { Positive } \\
\text { allometric }\end{array}$ & Confirmed \\
\hline $\begin{array}{l}\text { Plagioscion } \\
\text { squamosissimus }\end{array}$ & 14 & $\mathrm{~F}<0.0001$ & 2.6 & $1.01(=1)$ & $\begin{array}{l}\text { Negative } \\
\text { allometric }\end{array}$ & $\begin{array}{l}\text { Not confirmed } \\
\text { Isometric }\end{array}$ \\
\hline $\begin{array}{l}\text { Megalops } \\
\text { atlanticus }\end{array}$ & 23 & $\mathrm{~F}<0.0001$ & 3.04 & $1.01(=1)$ & $\begin{array}{l}\text { Positive } \\
\text { allometric }\end{array}$ & $\begin{array}{l}\text { Not confirmed } \\
\text { Isometric }\end{array}$ \\
\hline $\begin{array}{l}\text { Hoplias } \\
\text { malabaricus }\end{array}$ & 16 & $\mathrm{~F}<0.0001$ & 3.24 & $1.01(=1)$ & $\begin{array}{l}\text { Positive } \\
\text { allometric }\end{array}$ & $\begin{array}{l}\text { Not confirmed } \\
\text { Isometric }\end{array}$ \\
\hline $\begin{array}{l}\text { Cichla monoculus } \\
\text { Brachyplatystoma }\end{array}$ & 12 & $\mathrm{~F}<0.0001$ & 3.07 & $1.01(=1)$ & $\begin{array}{l}\text { Positive } \\
\text { allometric }\end{array}$ & $\begin{array}{l}\text { Not confirmed } \\
\text { Isometric }\end{array}$ \\
\hline $\begin{array}{l}\text { vaillantii } \\
\text { Boulengerella } \\
\text { cuvieri }\end{array}$ & 17 & $\mathrm{~F}<0.0001$ & 3.36 & $\begin{array}{l}1.005 \\
(=1)\end{array}$ & $\begin{array}{l}\text { Positive } \\
\text { allometric }\end{array}$ & $\begin{array}{l}\text { Not confirmed } \\
\text { Isometric }\end{array}$ \\
\hline $\begin{array}{l}\text { Ageneiosus } \\
\text { inermis }\end{array}$ & 10 & $\mathrm{~F}<0.0001$ & 3.42 & $\begin{array}{l}1.003 \\
(=1)\end{array}$ & $\begin{array}{l}\text { Positive } \\
\text { allometric }\end{array}$ & Confirmed \\
\hline Hoplias aimara & 63 & $\mathrm{~F}<0.0001$ & 3.16 & $\begin{array}{l}1.003 \\
(=1)\end{array}$ & $\begin{array}{l}\text { Positive } \\
\text { allometric }\end{array}$ & $\begin{array}{l}\text { Not confirmed } \\
\text { Isometric }\end{array}$ \\
\hline
\end{tabular}

Figure 3. Relationship between the $\mathrm{Hg}$ Concentration $\left(\mathrm{mg} \mathrm{Kg}^{-1}\right.$ ) and the Standard Length of Serrasalmus rhombeus, Hoplias malabaricus, Brachyplatystoma vaillantii, Cichla monoculus and Hoplias aimara.
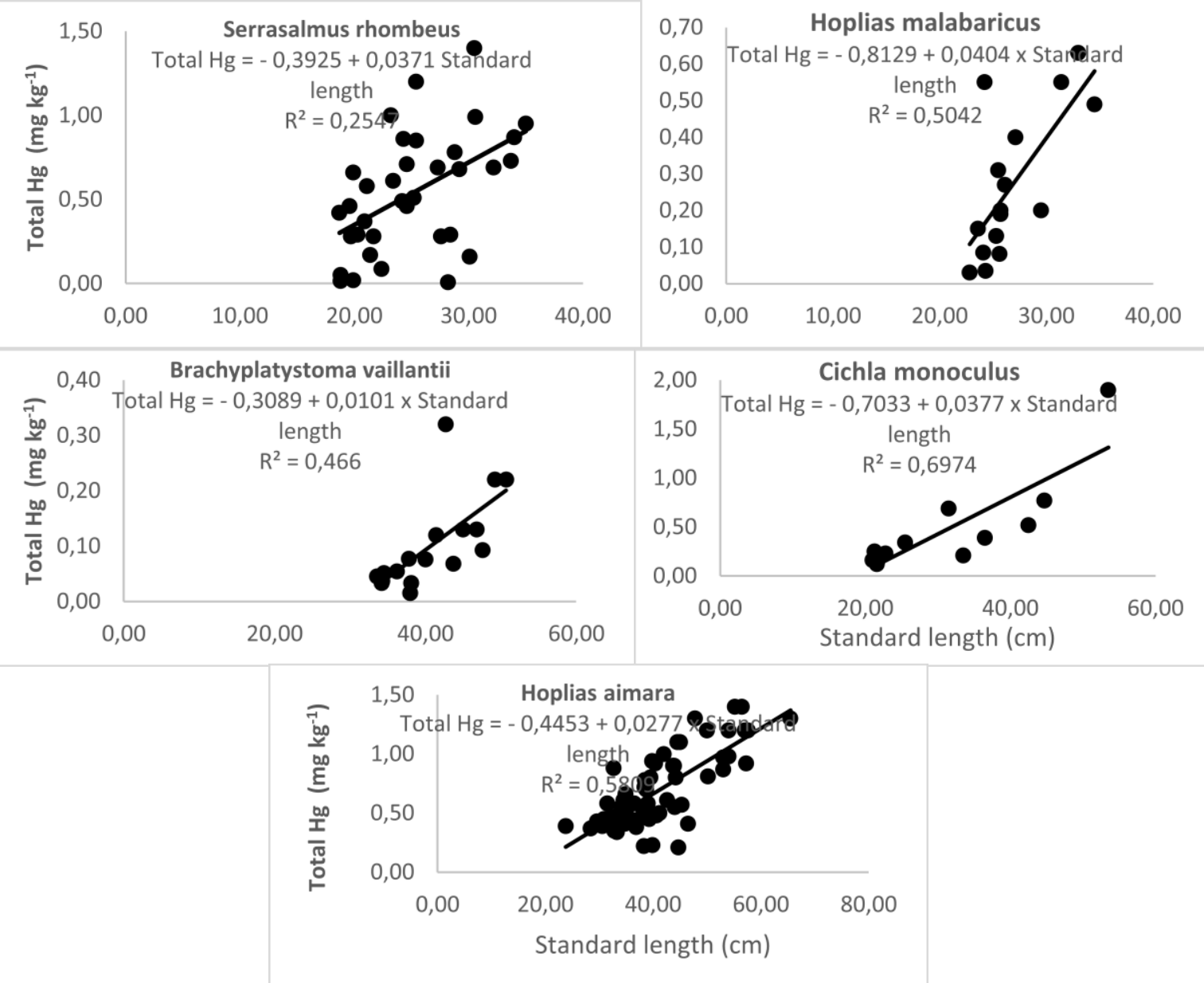

positive relationship between $\mathrm{Hg}$ and standard length (but not weight) for Cichla temensis in the Negro river.
Ageneiosus inermis and Boulengerella cuvieri showed high concentrations of mercury, and Venturieri et al. (2017) 
Figure 4. Relationship between the $\mathrm{Hg}$ Concentration $\left(\mathrm{mg} \mathrm{Kg}^{-1}\right.$ ) and the Weight of Serrasalmus rhombeus, Hoplias malabaricus, Brachyplatystoma vaillantii, Cichla monoculus and Hoplias aimara.

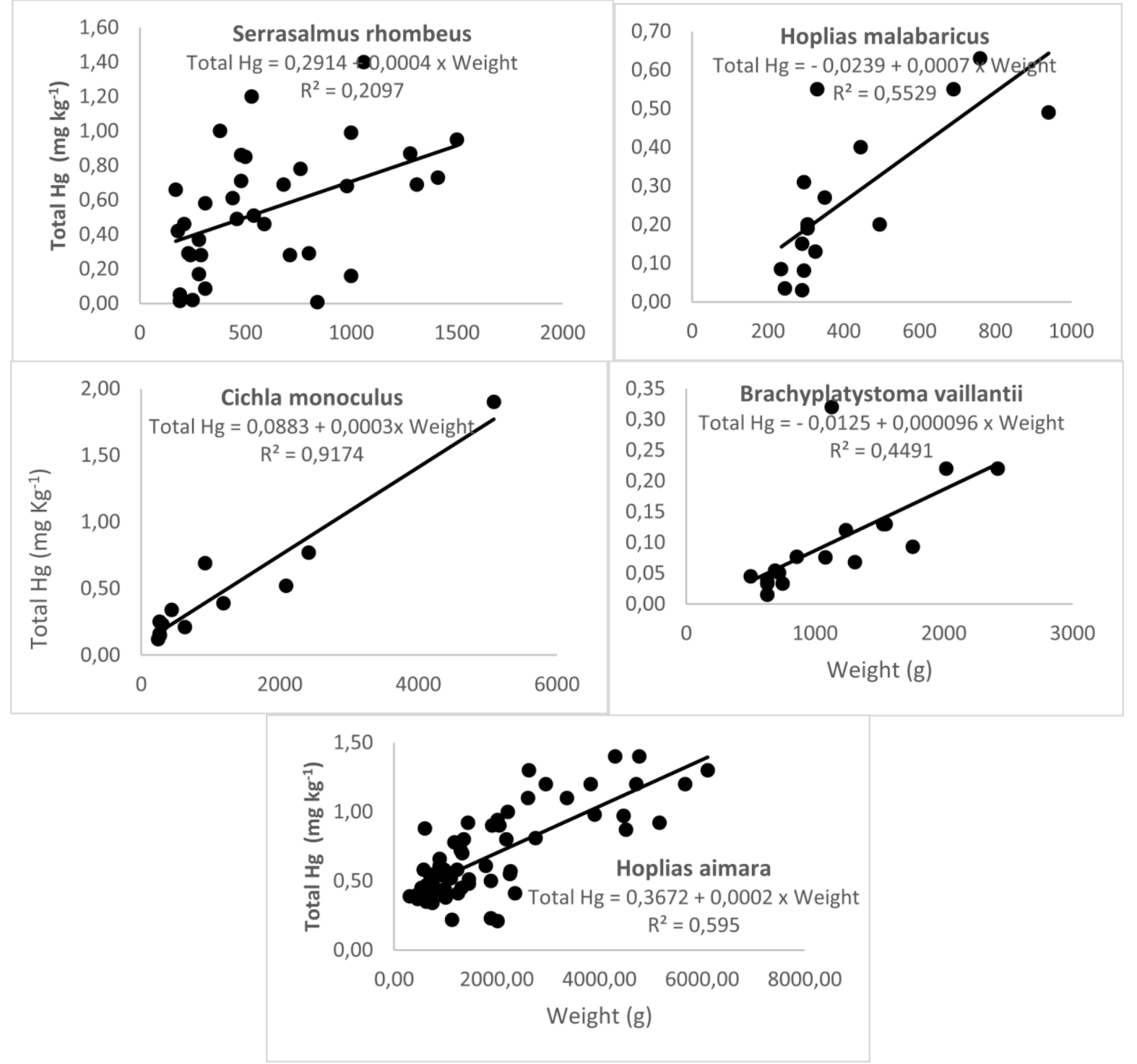

reported similarly high levels in rivers in Amapá. However, no relationship was observed between this metal and body weight or length. Ageneiosus inermis is considered a carnivorous species (DARY et al., 2017), but the diet of a related species in Amapá's Araguari River, A. ucayalensis, includes other important items such as crustaceans (SÁOLIVEIRA et al., 2014 (b)). If similarly true of $A$. inermis, this plasticity in diet could explain the fact that there is no positive relationship between mercury and the body weight and length of this species. Boulengerella cuvieri is considered piscivorous (SÁ-OLIVEIRA et al., 2014 (a); DARY et al., 2017), but the diet of this species when young is too poorly known to understand the relationship between mercury contamination and body weight and length.

Megalops atlanticus showed some mercury concentration in all samples. But, those values were low and no relationship was found between $\mathrm{Hg}$ concentration and the body weight and length in this species. Megalops atlanticus generally feeds on fish, but also consumes insects and vegetable matter. The proportion of these items in its diet can change throughout the year according to their availability in the environment, as noted by Cataño and Garzón-Ferreira (1994) in the coastal region of Colombia.

The catfish Brachyplatystoma vaillantii did not exhibit a high concentration of $\mathrm{Hg}$, but showed a positive relationship between $\mathrm{Hg}$ and body weight and length, in contrast to the results of Bastos et al. (2008) for fishes of the same genera from the Madeira River.

Hoplias aimara showed high concentrations of $\mathrm{Hg}$ and $\mathrm{a}$ positive relationship between this contaminant and body weight and length. High concentrations of $\mathrm{Hg}$ for this species also were found by Venturieri et al. (2017) in different rivers in Amapá, by Fréry et al. (2001) in the Maroni river, French Guiana and by Lima et al. 2015 for the Cassiporé River 
(Amapá). Fréry et al. (2001) also found a positive relationship between $\mathrm{Hg}$ and the body weight of Hoplias aimara in French Guiana.

\section{CONCLUSIONS}

All of the carnivorous fish species analyzed in this study showed some level of mercury contamination, but did not necessarily exhibit levels higher than that considered safe for consumption by WHO. The bioaccumulation potential of $\mathrm{Hg}$ was observed for Serrasalmus rhombeus, Hoplias malabaricus, Cichla monoculus and Brachyplatystoma vaillantii, all of which showed a positive relationship between weight and / or length and the total body $\mathrm{Hg}$ concentration. Environmental conditions and dietary plasticity can interfere with the degree of contamination and bioaccumulation of mercury among carnivorous / piscivorous species of fishes.

\section{ACKNOWLEDGMENTS}

This research was led by the WWF in close partnership with the Instituto de Pesquisa e Formação Indígena (lepé), Fundação Oswaldo Cruz, ICMBio, and the Amapá Institute of Scientific and Technological Research (IEPA). We acknowledge the support from ICMBio in the implementation of field work, particularly Iranildo Coutinho, Ricardo Pires, and Christoph Jaster. We thank the Amapá Institute of Scientific and Technological Research (IEPA) and the local inhabitants for their assistance with field work. We also thank to Mark H. Sabaj for the language revision of the text.

\section{BIBLIOGRAPHY}

ANVISA - Agência Nacional de Vigilância Sanitária. Regulamento técnico Mercosul sobre limites máximos de contaminantes inorgânicos em alimentos. Resolução de agosto de 2013. Acesso em 11 de maio de 2018, em www.portal.anvisa.gov.br/documents/10181/3745585/R DC 422013 .pdf/4dbd197d-00cb-4a97-b5ff-0216e

$1 \mathrm{e} 172 \mathrm{~d} 7$

AZEVEDO, F.A. Toxicologia do mercúrio. São Carlos: Rima, 2003

AZEVEDO-SILVA, C. E.; ALMEIDA, R.; CARVALHO, D. P.; OMETTO, J. P. H. B.; CAMARGO, P. B.; DORNELES, P. R.; AZEVEDO, A.; BASTOS, W. R.; MALM, O.; TORRES, J. P. M. Mercury biomagnification and the trophic structure of the ichthyofauna from a remote lake in the Brazilian Amazon.Environmental Research, v. 151, p. 286-296,
2016. DOI:10.1016/j.envres.2016.07.035

BARBOSA, A. C.; SOUZA, J.; DÓREA, J. G.; JARDIM, W. F.; FADINI, P. S. Mercury Biomagnification in a Tropical Black Water, Rio Negro, Brazil. Archives of Environmental Contamination and Toxicology, v. 45, p. 235--246, 2003.

BASTOS, W. R. Mercury in the environment and riverside population in the Madeira River Basin, Amazon, Brazil. Science of the Total Environment, v. 368, p. 344-351, 2006.

BASTOS, W. R.; ALMEIDA, R.; DÓREA, J. G.; BARBOSA, A. C. Annual flooding and fish-mercury bioaccumulation in the environmentally impacted Rio Madeira (Amazon). Ecotoxicolog, v. 16, n. 3, p. 341-346, 2007.

BASTOS, W. R.; REBELO, M. F.; FONSECA, M. F.; ALMEIDA, R; MALM, O. A description of Mercury in fishes from the Madeira River Basin, Amazon, Brazil. Acta Amazonica, v. 38, n. 3, p. 421-430, 2008.

BELTRAN-PEDREROS, S.; ZUANON, J.; LEITE, R. G.; PELEJA, J. R. P.; MENDONÇA, A. B.; FORSBERG, B. R. Mercury bioaccumulation in fish of commercial importance from different trophic categories in an Amazon floodplain lake. Neotropical Ichthyology, v. 9, n. 4, p. 901-908, 2011.

BRUGGEMAN, W. A. Hidrophobic interactions in the aquatic environment. In: HUTZINGER, O. (ed.). The handbook of environmental chemistry, Germany: Spring-Verlag, v. 2, 205 p., 1982.

CALLEGARI-JACQUES, S. M. Bioestatística: princípios e aplicações. Porto Alegre: Artmed, 2007.

CARRASCO, L.; BENEJAM, L.; BENITO, J.; BAYONA, J. M.; DÍEZ, S. Methylmercury levels and bioaccumulation in the aquatic food web of a highly mercury-contaminated reservoir. Environment International, v. 37, p. 12131218. 2011.

CASTILHOS, Z. C.; BIDONE, E. D. Hg biomagnification in the ichthyofauna of the Tapajós river region, Amazonia, Brazil. Bulletin of Environmental Contamination and Toxicology, v. 64, p. 693-700. 2000.

CATAÑO, S.; GARZÓN-FERREIRA, J. 1994. Ecología trófica del sábalo Megalops atlanticus (Pisces: Megalopidae) en el área de Ciénaga Grande de Santa Marta, Caribe colombiano. Rev. Biol. Trop., v. 42, n. 3, p. 673-684, 1994.

DARY, E. P.; FERREIRA, E.; ZUANON, J.; RÖPKE, C. P. Diet and trophic structure of the fish assemblage in the midcourse of the Teles Pires River, Tapajós River basin, Brazil. Neotropical Ichthyology, v. 15, n. 4, p. e160173, 2017.

DÓREA, J. G.; BARBOSA, A C. Anthropogenic impact of mercury accumulation in fish from the Rio Madeira and Rio Negro rivers (Amazônia). Biological Trace Element Research, v. 115, p. 243-254, 2007.

DOREA, J. G.; BARBOSA, A. C.; SILVA, G. S. Fish mercury bioaccumulation as a function of feeding behavior and 
hydrological cycles of the Rio Negro, Amazon. Comparative Biochemistry and Physiology, p. 275-283, 2006.

FRÉRY, N.; MAURY-BRACHET, R.; MAILLOT, E.; DEHEEGER, M.; DE MÉRONA, B.; BOUDOU, A. Gold-Mining Activities and Mercury Contamination of Native Amerindian Communities in French Guiana: Key Role of Fish in Dietary Uptake. Environmental Health Perspectives, v. 109, n. 5, p. 449-456, 2001.

IPCS. Environmental Health Criteria 101: Methyl-mercury. World Health Organization. Geneva. 141p., 1990.

KING, M. Fisheries biology assessment and management. Fishing New Books, Osney Mead, Oxford England, 342p., 1996.

LE CREN, E. D. The length-weight relationship and seasonal cicle in gonad weight and condition in the perch (Perca fluviatilis). Journal of Animal Ecology, v. 20, p. 201-219, 1951.

LIMA, D. P.; SANTOS, C.; SILVA, R. S.; YOSHIOKA, E. T. O.; BEZERRA, R. M. Contaminação por metais pesados em peixes e água da bacia do rio Cassiporé, Estado do Amapá, Brasil. Acta Amazonica, v. 45, n. 4, p. 405-414, 2015. http://dx.doi.org/10.1590/1809-4392201403995.

MALM, O.; CASTRO, M. B.; BASTOS, W. R.; BRANCHES, F. J. P.; GUIMARÃES, J. R. D.; ZUFFO, C. E.; PFEIFFER, W. C. An assessment of $\mathrm{Hg}$ pollution in different goldminning areas, Amazon Brazil. Sci Total Environ, v. 175, p. 127 140, 1995.

MÉRONA, B.; RANKIN-DE-MÉRONA, J. Food resource partitioning in a fish community of the central Amazon floodplain. Neotropical Ichthyology, v. 2, n. 2, p. 75-84, 2004.

MIRANDA, M. R.; SOUSA-COELHO, S. A.; GUIMARÃES, J. R. D.; CORREA, R. R. S.; OLIVEIRA, D. Mercúrio em sistemas aquáticos: Fatores ambientais que afetam a metilação. Oecologia Brasiliensis, v. 11, n. 2, p. 240-251, 2007.

MS - Ministério da Saúde. 1998. Princípios gerais para o estabelecimento de níveis máximos de tolerância para contaminantes inorgânicos: Limites máximos de tolerância para contaminantes inorgânicos. Secretaria de Vigilância Sanitária, Agência Nacional de Vigilância Sanitária. Portaria no. 685 de 27.08.98, DOU de 28.08.1998.

NEVADO, J. J. B.; MARTIN-DOIMEADIOS, R.; BERNARDO, F. J. G.;, MORENO, M. J.;, HERCULANO, A. M.; NASCIMENTO, J. L. M.;, \& CRESPO-LÓPEZ, M. E. Mercur in the Tapajós River basin,Brazilian Amazon; a review. Environment International, v. 36 , n. 6, p. 593-608, 2010. DOI: 10.1016/j.envint.2010.03.011

RODRIGUES, A. P. C.; CARVALHEIRA, R. G.; CESAR, R. G.; BIDONE, E. D.; CASTILHOS, Z. C.; ALMOSNY, N. R. P.
Bioacumulação de Mercúrio em Quatro Espécies de Peixes Tropicais Oriundos de Ecossistemas Estuarinos do Estado do Rio de Janeiro, Brasil. Anuário do Instituto de Geociências - UFRJ, v. 33, n. 1, p. 54-62, 2010.

ROULET, M.; MAURY-BRACHET, R. Le mercure dans les organisms aquatiques amazoniens. In: Carmouse, J.P., LUCOTTE, M., BOUDOU, A., (Eds). Le mercure en Amazonie. Rôle de L'homme et de L'environment, risques sanitaries. IRD editions. Paris. 494p., 2001.

SAMPAIO DA SILVA, D.; LUCOTTE, M.; ROULET, M.; POIRIER, H.; MERGLER, D.; CROSSA, M. Mercúrio nos peixes do Rio Tapajós, Amazônia brasileira. Interfacehs, p. 1-31, 2006.

SÁ-OLIVEIRA, J. C.; ANGELINI, R.; ISAAC-NAHUM, V. J. Diet and niche breadth and overlap in fish communities within the area affected by an Amazonian reservoir (Amapá, Brazil). Anais da Academia Brasileira de Ciências, v. 86, n. 1, p. 383-405, 2014.

SÁ-OLIVEIRA, J. C.; MACIEL, A. G. P.; ARAÚJO, A. S.; ISAACNAHUM, V. J. Dieta do Mandubé, Ageneiosus ucayalensis (Castelnau, 1855), (Osteichthyes: Auchenipteridae) do Reservatório da Usina Hidrelétrica Coaracy Nunes, Ferreira Gomes-Amapá, Brasil. Biota Amazônia, v. 4, n. 3, p. 73-82. 2014.

SCHEUHAMMER, A.; BRAUNE, B.; CHAN, H. M.; FROUIN, H.; KREY, A.; LETCHER, R.; LOSETO, L.; NOEL, M.; OSTERTAG, S.; ROSS, P.; WAYLAND, M. Recent progress on our understanding of the biological effects of mercury in fish and wildlife in the Canadian Arctic. Science of the Environment, 509-510, 91-103, 2015. DOI: 10.1016/ j.scitotenv.2014.05.142

SOARES, J. L. F.; GOCH, Y. G. F.; PELEJA, J. R. P.; FORSBERG, B. R.; LEMOS, E. J. S.; SOUSA, O. P. 2016. Bioacumulação de Mercúrio Total ( $\mathrm{HgT}$ ) e hábitos alimentares de peixes da bacia do Rio Negro, Amazônia, Brasil. Biota Amazônia, v. 6, n. 1, p. 102-106,. 2016.

STEFANI, P. M.; ROCHA, O. Diet composition of Plagioscion squamosissimus (Heckel, 1840), a fish introduced into the Tietê River system. Braz. J. Biol., v. 69, n. 3, p. 805-812, 2009.

VENTURIERI, R.; OLIVEIRA-DA-COSTA, M.; GAMA, C.; JASTER, C. B. 2017. Mercury Contamination within Protected Areas in the Brazilian Northern Amazon-Amapá State. American Journal of Environmental Sciences, v. 13, n. 1, p. 11-21, 2017.

VERA, Y. M; CARVALHO, R. J.; CASTILHOS, Z. C.; KURTZ, M. J. R. Mercury Bioaccumulation in the Brazilian Amazonian Tucunares (Cichla sp., Cichlidae, Perciformes). Revista Ambi-Água, Taubaté, v. 3, n. 2, p. 19-27, 2008.

WHO. Environmental Health Criteria (EHC 101). Methylmercury. Geneva, 1990. 143p., 1990.

ZAR, J. H. Biostatistical analysis. 3rd ed. New Jersey: Prentice 
Hall, 1996. 662 p., 1996.

ZHOU, H. Y.; WONG, M. H. Mercury accumulation in freshwater fish with emphasis on the dietary influence.

Water Research, v. 34, n. 17, p. 4234-4242, 2007. DOI: 10.1016/S0043-1354(00)00176.

\section{Submissão: 06/10/2020}

Aprovado para publicação: 14/11/2020 